\title{
PENINGKATAN PRESTASI BELAJAR PKn MELALUI TUGAS PROYEK BERBANTUAN WEBSITE DI SDN GEGUNUNG KULON, KAB. REMBANG
}

\author{
IMPROVING LEARNING ACHIEVEMENT ON CIVICS (PKn) THROUGH WEBSITE- \\ ASSISTED PROJECT TASK IN SDN GEGUNUNG KULON, KAB. REMBANG \\ Parlan \\ SDN Gegunung Kulon Rembang \\ parlan72_asa@yahoo.co.id
}

Diterima: 23 Februari 2016; dikembalikan untuk direvisi: 29 Maret 2016; disetujui: 9 April 2016

\begin{abstract}
ABSTRAK
Tujuan penelitian ini adalah mendeskripsikan proses pembelajaran, mengetahui peningkatan prestasi siswa, dan mendeskripsikan perubahan perilaku siswa dalam pembelajaran PKn melalui tugas proyek berbantuan website. Penelitian ini dilaksanakan dalam 2 Siklus dengan subjek siswa kelas IV SD Negeri Gegunung Kulon, Kabupaten Rembang, semester 2 tahun pelajaran 2014/2015. Data penelitian dianalisis dengan metode deskriptif komparatif, membandingkan proses dan hasil belajar antara praSiklus, Siklus I dan Siklus II. Hasil penelitian yang dilaksanakan 2 Siklus menunjukkan peningkatan aktivitas siswa sampai 86 persen baik. Hasil belajar siswa juga meningkat ditandai Siklus I nilai rata-rata kelas 67,86 dan ketuntasan mencapai 57 persen. Siklus II nilai rata-rata kelas 78,57 dan ketuntasan 86 persen. Kesimpulan penelitian ini adalah aktivitas dan hasil belajar siswa meningkat dalam mengikuti pembelajaran serta ada perubahan perilaku siswa untuk mengikuti pembelajaran PKn melalui tugas proyek berbantuan website yang semula pasif menjadi lebih aktif. Semua siswa berminat dalam melaksakanan tugas dan memperoleh pengalaman yang menyenangkan dalam menjelajah website atau internet.
\end{abstract}

Kata kunci: prestasi belajar, pembelajaran PKn, tugas proyek, website

\begin{abstract}
The objective of this research was to describe learning process, to know how students' learning achievement improve, and to describe the change of student behavior on civics learning through website-assisted project task. The research was done through two cycles, with grade IV students in SD Negeri Gegunung Kulon throughout the second semester of school year 2014/2015 as the subject. Research data analysis was done using descriptive comparative method, comparing the learning process and result between pra-cycle, first cycle and second cycle. The result showed positive increase of students' activities as much as 86 percent. The improvement of students' learning achievement in cycle I could be seen by the class average grade of 67,86 and mastery learning of 57 percent, while in cycle II the class average grade was 78,57 and mastery learning of 86 percent. The conclusion was that students' learning activities and achievement improved and there was also a changing in students' behavior in learning civics through website-assisted project task, from passive learning to active learning. Every student showed interest in doing the project and gaining enjoyable experience browsing the internet.
\end{abstract}

Key word: learning achievement, civics, project task, website 


\section{PENDAHULUAN}

Semangat kebangsaan dan rasa cinta tanah air dalam kehidupan bermasyarakat, berbangsa, dan bernegara yang berdasarkan Pancasila dan Undang-Undang dasar 1945, perlu ditanamkan sejak dini, termasuk kepada peserta didik. Salah satu ruang lingkup pembelajaran PKn yang sesuai dengan maksud tersebut adalah mengenal sistem pemerintahan daerah sampai tingkat pusat. Pengenalan ini diharapkan agar peserta didik mengenal pengelolaan Negara.

Contoh pembelajaran yang berkaitan dengan pengelolaan Negara adalah tentang sistem Pemerintahan Pusat. Materi ini terdapat pada Standar Kompetensi (SK) 3 yaitu mengenal sistem Pemerintahan Pusat (Depdiknas 2004: 28). Pada kondisi awal pembelajaran tentang sistem Pemerinatan Pusat ini, prestasi belajar yang diperoleh rendah dengan ditandai nilai rata-rata kelas 62,14 dan belum mencapai tuntas belajar secara klasikal. Dari 14peserta didik hanya 5 peserta didik yang memperoleh nilai di atas Kriteria Ketuntasan Minimal (KKM). Jadi sebagaian besar peserta didik atau 64 persen masih dinyatakan belum berhasil, karena nilai yang diperoleh di bawah batas KKM mata pelajaran PKn di SD Negeri Gegunung Kulon Kecamatan Rembang, yaitu 68.

Dari segi keaktifan peserta didik, belum semua peserta didik menunjukkan keaktifan hanya peserta didik tertentu yang aktif bertanya dan menjawab. Sedangkan pada kerja kelompok hanya peserta didik tertentu yang mengerjakan dan yang lain sebagai pendengar saja. Keadaan ini tentu kurang menyenangkan dan tidak menciptakan suasana belajar yang menyenangkan dan mendidik. Sedangkan cakupan materi sangat luas sedang sumber buku terbatas. Untuk memecahkan masalah tersebut, disajikan pembelajaran PKn tentang mengenal sistem pemerintahan pusat pada peserta didik kelas IV, dengan memberi tugas proyek berbantuan website. Hal ini dimaksudkan agar peserta didik dapat mencari materi yang sebanyakbanyaknya sehingga memiliki wawasan yang luas, sesuai dengan tugasnya melalui website dengan cara mengunduh materi pembelajaran PKn tersebut.

Dalam penelitian ini, dibatasi hal-hal sebagai berikut, (i) Peserta didik yang dimaksud adalah peserta didik kelas IV SDN Gegunung Kulon Kecamatan Rembang Kabupaten Rembang, semester 2 tahun pelajaran 2014/2015, (ii) Materi pelajaran adalah pada mata pelajaran PKn tentang mengenal sistem pemerintahan tingkat pusat, (iii) Tugas proyek yang dimaksud adalah tugas yang dibebankan pada siswa untuk menyusun materi atau modul tentang sistem Pemerintahan tingkat Pusat dengan cara mengunduh melalui website/internet, dan (iv) website yang ada di jaringan internet dengan cara mengetik kata kunci untuk masuk pada laman yang dituju baik web atau blog. Kata kunci yang 
dimaksud adalah sekitar masalah pemerintahan pusat, legislatif, eksukutif, lembaga Negara, organisasi pemerintahan pusat, dan seputar tugas fungsi lembaga negara.

Mengacu pada hal-hal tersebut di depan, maka dapat dirumuskan permasalahannya yaitu: (i) bagaimanakah proses pembelajaran kompetensi mengenal sistem pemerintahan pusat melalui tugas proyek berbantuan website pada peserta didik kelas IV SD Negeri Gegunung Kulon Kecamatan Rembang Kabupaten Rembang semester 2 Tahun Pelajaran 2014/2015; (ii) seberapa besar peningkatan prestasi belajar setelah mengikuti pembelajaran melalui tugas proyek berbantuan website pada peserta didik kelas IV SD Negeri Gegunung Kulon, semester 2 tahun pelajaran 2014/2015; dan (iii) bagaimana perubahan perilaku setelah mengikuti pembelajaran melalui tugas proyek berbantuan website pada peserta didik kelas IV SD Negeri Gegunung Kulon Rembang semester 2 tahun pelajaran 2014/2015. Tujuan penelitian ini adalah: (i) mendeskripsikan proses pembelajaran kompetensi mengenal sistem pemerintahan tingkat pusat melalui tugas proyek berbantuan website, (ii) mengetahui peningkatan prestasi peserta didik setelah mengikuti pembelajaran tentang mengenal sistem pemerintahan pusat melalui tugas proyek berbantuan website, dan (iii) mendeskripsikan perubahan perilaku setelah mengikuti pembelajaran kompetensi mengenal sistem pemerintahan pusat melalui tugas proyek berbantuan website pada peserta didik kelas IV SD Negeri Gegunung Kulon Rembang semester 2 tahun pelajaran 2014/2015.

Hasil dari pelaksanaan penelitian tindakan kelas ini akan memberikan manfaat yang langsung maupun tidak langsung oleh siswa, guru, sekolah, dan KKG. Bagi siswa, manfaatnya adalah (i) dapat meningkatkan kemampuan siswa dalam mengenal Negara Indonesia; (ii) dapat memberikan pengalaman baru bagi siswa terhadap pemanfaatan teknologi informasi, sehingga mendorong minat dan motivasi siswa dalam pembelajaran PKn. Manfaat bagi guru adalah (i) mengetahui kekurangan yang ada dalam dirinya dan dapat dipergunakan perbaikan untuk pembelajaran berikutnya; (ii) memiliki pengalaman dalam pemanfaatan teknologi informasi. Manfaat bagi sekolah adalah (i) memberikan sumbangan yang berguna untuk proses pembelajaran di sekolah itu; (ii) memberikan dorongan untuk melakukan penelitian tindakan kelas terhadap guru lain. Sedangkan manfaatnya bagi Kelompok Kerja Guru (KKG) adalah (i) sebagai bahan diskusi untuk pengembangan kegiatan profesi di tingkat KKG; (ii) bahan referensi untuk mengadakan kegiatan penelitian serupa di sekolah lain.

\section{Hipotesis Tindakan}


Hipotesis tindakan penelitian ini adalah (i) pemberian tugas proyek berbantuan website diduga dapat meningkatkan keaktifan peserta didik; (ii) penggunaan metode tugas proyek berbantuan website diduga dapat meningkatkan prestasi belajar peserta didik dalam pembelajaran tentang mengenal sistem pemerintahan pusat; dan (iii) pemberian tugas proyek berbantuan website diduga dapat mengubah perilaku belajar tentang mengenal sistem pemerintahan pusat pada peserta didik kelas V SD Negeri Gegunung Kulon Rembang semester 2 tahun pelajaran 2014/2015.

\section{KAJIAN LITERATUR}

\section{Pembelajaran Pendidikan}

\section{Kewarganegaraan (PKn)}

Tujuan PKn adalah untuk membentuk watak atau karakteristik warga negara yang baik. Sedangkan tujuan pembelajaran mata pelajaran ini adalah untuk menjadikan siswa (i) mampu berpikir secara kritis, rasional, dan kreatif dalam menanggapi persoalan hidup maupun isu kewarganegaraan di negaranya; (ii) mau berpartisipasi dalam segala bidang kegiatan, secara aktif dan bertanggung jawab, sehingga bisa bertindak secara cerdas dalam semua kegiatan, dan (iii) bisa berkembang secara positif dan demokratis, sehingga mampu hidup bersama dengan bangsa lain di dunia dan mampu berinteraksi, serta mampu memanfaatkan teknologi informasi dan komunikasi dengan baik (Ruminiati, 2006). Sejalan dengan itu, merupakan mata pelajaran yang memfokuskan pada pembentukan warganegara yang memahami dan mampu melaksanakan hak-hak dan kewajibannya untuk menjadi warganegara Indonesia yang cerdas, terampil, dan berkarakter yang diamanatkan oleh Pancasila dan UUD 1945 (Tijan, 2008).

Berdasarkan pendapat tersebut dapat disimpulkan bahwa mata pelajaran PKn bertujuan untuk membentuk warga negara yang baik yang tahu hak dan kewajibannya yang dilaksanakan dalam kehidupan seharihari.

Untuk mewujudkan hal itu perlu dilaksanaakan pembelajaran yang baik. Pembelajaran yang baik adalah pembelajaran yang menyenangkan, mendidik, dan membebaskan siswa dari semua belenggu. Untuk mencapai semua itu pembelajaran harus disesuaikan dengan kebutuhan, minat dan motivasi siswa, serta karakteristik siswa khususnya siswa sekolah dasar. Proses pembelajaran yang menyenangkan, adalah proses pembelajaran yang dapat menciptakan suasana dan iklim belajar yang kondusif sehingga peserta didik merasa aman, nyaman, betah, dan asyik untuk mengikutinya. Untuk ini pendidik perlu berpenampilan menarik, bersahabat, adil, penuh kasih, memiliki rasa humor, namun harus tetap berwibawa, disiplin, dan bertanggung jawab (Haryono dan Jaino 2008). Untuk mewujudkan pembelajaran PKn yang menyenangkan siswa 
diajak untuk menjelajah website atau internet mengunduh materi tentang sistem pemerintahan pusat.

Bertolak dari pembelajaran yang menyenangkan dan mendidik, maka pembelajaran hendaknya dilengkapi dengan prinsip pembelajaran yang membebaskan agar siswa tidak terbelenggu dengan doktrin dan aturan yang menakutkan. Pembelajaran yang membebaskan, yang tidak membelenggu dan memenjarakan kebebasan peserta didik untuk berekspresi, bereksperimen, dan berprakarsa untuk mengembangkan kreativitas dan bersikap kritis, serta penuh tanggungjawab (Haryono dan Jaino, 2008).

Hal ini akan mudah tercapai jika pendidikan nilai moral dan norma tetap ditanamkan pada siswa sejak usia dini, karena jika siswa sudah memiliki nilai moral yang baik, maka tujuan untuk membentuk warga negara yang baik akan mudah diwujudkan. Pembelajaran PKn diupayakan penggunaan teknologi informasi dan komunikasi yaitu pemanfaatan internet atau website.

Pada penelitian ini fokus pada materi PKn tentang mengenal sistem pemerintahan tingkat pusat. Tujuan pembelajaran PKn tentang mengenal sistem pemerintahan pusat adalah bahwa setelah mempelajari materi ini siswa diharapkan dapat mengenal sistem pemerintahan pusat, sehingga dapat menjadi warga Negara yang tahu hak dan kewajibannya (Bestari dan Sumiati, 2008). Untuk memperdalam sekaligus memperluas materi ini, penulis memanfaatkan website atau internet untuk mengunduh materi dalam bentuk tugas yang diberikan pada siswa.

Berdasarkan uraian di atas, dapat disimpulkan bahwa tujuan PKn di SD adalah untuk menjadikan warganegara yang baik, yaitu warganegara yang tahu, mau, dan sadar akan hak dan kewajibannya. Dengan demikian, kelak siswa diharapkan dapat menjadi bangsa yang terampil dan cerdas, dan bersikap baik, serta mampu mengikuti kemajuan teknologi modern. Oleh karena itu dalam menanamkan nilai-nilai sebagai warga Negara yang tahu hak dan kewajibannya yang berkaitan dengan tata negara disampaikan dengan memanfaatkan teknologi informasi dan komunikasi, berupa mengunduh materi tentang lembaga negara melalui website atau internet.

\section{Metode Tugas}

Tujuan pembelajaran akan dapat tercapai secara optimal jika pemilihan strategi dan metodenya tepat. Agar proses belajar mengajar dapat terlaksana dengan baik, dalam pelaksanaan pembelajaran dapat dipilih satu atau lebih metode. Metode, adalah cara yang digunakan oleh guru dan siswa dalam mengolah informasi yang berupa fakta, data, dan konsep pada proses pembelajaran yang mungkin terjadi dalam suatu strategi. Dalam pembelajaran, metode yang dapat digunakan 
banyak sekali ragamnya (Sagala dalam Ruminiati, 2006). Guru hendaknya pandai menggunakan atau memilih metode yang tepat dan sesuai dengan materi dan kondisi siswa, sehingga tujuan pembelajaran dapat tercapai.

Metode tugas ini dipertegas dengan tugas proyek berbantuan website atau internet. Artinya bahwa tugas yang disusun bersumber dari website atau internet, yaitu menyusun modul atau kumpulan materi tentang mengenal sistem pemerintahan, arti pemerintahan, tugas fungsi lembaga negara, organisasi lembaga negara. Pencarian, penemuan, dan pengunduhan materi itu melalui website, dikemas dalam tugas proyek berbantuan website.

Metode pemberian tugas adalah metode yang dilakukan oleh guru terhadap siswa, yang biasanya lebih banyak dikerjakan di rumah atau di luar sekolah karena penyelesaiannya memerlukan waktu yang lebih panjang (Ruminiati, 2006). Dalam mengerjakan tugas ini, siswa diperkenankan menggunakan internet di sekolah di luar jam pembelajaran tetapi masih dalam bimbingan guru. Kelebihan metode tugas ini adalah (i) dapat memupuk semangat belajar siswa, (ii) dapat lebih memperdalam, memperkaya, dan memperluas wawasan yang dipelajarinya, dan (iii) dapat membina siswa dalam pengolahan informasi.
Langkah-langkah dalam memberi tugas proyek ini adalah (i) guru memberi tugas kepada siswa untuk mengunduh materi tentang sistem pemerintahan tingkat pusat, satu minggu sebelum Siklus pembelajaran; (ii) hasil unduh dari internet/website digunakan sumber referensi pada saat pembelajaran Siklus 1 serta dipresentasikan pada saat pembelajaran; (iii) hasil unduh dari website yang sudah didiskusikan dikumpulkan atau dipajang; (iv) guru member tugas lagi kepada peserta didik untuk mengunduh materi melalui website untuk Siklus 2 yang diberikan satu minggu sebelum Siklus 2 dimulai; (v) hasil unduh yang telah diperoleh siswa digunakan dalam pembelajaran Siklus 2 untuk bahan referensi dan diskusi; (vi) semua hasil unduh dari website dikumpulkan menjadi kumpulan materi tentang sistem pemerintahan pusat.

Penerapan metode pemberian tugas, sebelumnya digunakan beberapa penelitian dalam pembelajaran PKn. Harlina, Hasdin dan Arif Firmansayah (2014) dalam penelitiannnya yang berjudul "Penerapan Metode Pemberian Tugas untuk Meningkatkan Rasa Tanggungjawab dalam Pembelajaran PKn di Kelas III SDN Baho Makmur Kecamatan Bahodopi Kabupaten Morowali”, menemukan bahwa hasil belajar siswa meningkat setelah mengalami pembelajaran menggunakan metode pemberian tugas. Pada Siklus I ketuntasan belajar individual 60 persen, pada Siklus II 
meningkat menjadi 100 persen. Persentase daya serap klasikal pada Siklus I 70,46 persen, dan pada Siklus II meningkat menjadi 93 persen. Nilai persentase ketuntasan klasikal pada Siklus I sebesar 90,2 persen, dan pada Siklus II meningkat menjadi 100 persen.

\section{Website}

Media internet yang memilki sifat interaktif, bisa sebagai media masa dan interpersonal, dan gudangnya sumber informasi dari berbagai penjuru dunia, sangat dimungkinkan menjadi media pendidikan yang lebih unggul. Setelah kehadiran guru dalam arti sebenarnya, internet akan menjadi suplemen dalam menjadikan wakil guru yang mewakili sumber belajar yang penting di dunia (Rahmawati 2008).

Sejalan dengan pendapat di atas, Mampuono (2009) juga berpendapat bahwa web atau internet merupakan media yang kaya informasi yang dapat dijadikan media pembelajaran yang baik, yang dapat membantu guru dan siswa dalam pembelajaran.

Berdasarkan pendapat tersebut dapat disimpulkan bahwa web atau internet dapat dijadikan media dan sumber belajar dalam proses pembelajaran di kelas. Kehadiran internet sangat membantu dalam dunia pendidikan. Saat ini web atau lebih di kenal dengan internet sudah tidak asing lagi di kalangan pelajar yang pasti pernah mengakses internet. Internet dapat diartikan sebagai jaringan komputer luas yang mendunia yaitu menghubungkan pemakai komputer dari suatu negara ke negara lain di seluruh dunia yang di dalamnya terdapat berbagai sumber daya informasi dari mulai yang statis hingga yang dinamis dan interaktif. Pembelajaran PKn di SD perlu mendapat sentuhan teknologi informasi internet.

Penelitian Pembelajaran PKn dengan memanfaatkan teknologi komputer sebelumnya yang dilaksanakan oleh Pertiwi, Sukadi dan Pursika (2008) menemukan bahwa penerapan strategi pembelajaran $e$ learning dapat meningkatkan hasil belajar siswa pembelajaran $\mathrm{PKn}$, rata-rata hasil belajar siswa sebesar 80,34 dengan ketuntasan klasikal 86 persen. Jumlah siswa yang tuntas 25 siswa sedangkan yang belum tuntas sebanyak 4 orang. Hal ini menunjukkan secara klasikal keseluruhan ketuntasan individual dan klasikal dalam Siklus II sudah terpenuhi.

Penelitian yang sama di atas juga dilaksanakan oleh Solikhin (2008) dengan menerapkan Teknologi Informasi dan Komunikasi (TIK). Dalam penelitiannya yang berjudul "Penggunaan Information, Communication and Technology dalam Pembelajaran: Perspektif Mata Pelajaran Matematika, IPA, IPS dan PKn di Ssekolah Dasar", menemukan bahwa menggunakan TIK dapat meningkatkan pemahaman 
terhadap pelajaran, meningkatkan motivasi, memberikan murid menentukan pembelajaran sendiri, mengakses informasi yang sukar diperoleh, meningkatkan kreativitas.

Penelitian berikutnya yang berkaitan dengan TIK atau berbasis multimedia dilaksanakan oleh Pawestri (2013) dengan judul penelitian: "Peningkatan kualitas Pembelajarn PKn Melalui Model Direct Instruction Berbasis Multimedia Pada Siswa Kelas VB SDN Sampangan 02 Kota Semarang”. Dalam pembelajaran berbasis multimedia tersebut di atas dapat diketahui bahwa pada Siklus I perolehan skor keterampilan guru yaitu 21 dengan kategori cukup, skor aktivitas siswa 20,74 dengan kategori baik dan prosentase ketuntasan 66,66 persen. Pada Siklus II perolehan skor keterampilan guru 27 dengan kategori baik, skor aktivitas siswa 21,38 dengan kategori baik dan prosentase ketuntasan 75 persen. Pada Siklus III perolehan skor keterampilan guru sebesar 31 dengan kategori sangat baik, skor aktivitas siswa 23,02 dengan kategori baik dan prosentase ketuntasan klasikal sebesar 94,4 persen.

\section{Kerangka Pikir}

Pembelajaran PKn yang memanfaatkan teknologi informasi atau website atau internet akan dapat menciptakan pembelajaran yang mengandung proses eksplorasi, elaborasi, dan konfirmasi sekaligus menyenangkan.
Kegiatan pembelajaran itu akan meningkatkan motivasi peserta didik untuk terlibat secara aktif, sehingga dapat meningkatkan prestasi belajar peserta didik.

Pemanfaatan website atau internet dalam mengerjakan tugas-tugas dapat membawa suasana hati yang senang dan menyenangkan peserta didik, sehingga peserta didik senantiasa berminat dalam mengerjakan tugas dan optimal. Hal ini merupakan salah satu upaya menciptakan situasi belajar yang menyenangkan. Pembelajaran ini juga membawa peserta didik pada proses pembelajaran yang membebaskan tanpa paksaan sekaligus menyenangkan.

Proses unduh materi dari website merupakan proses aktif bagian dari pembelajaran. Berawal dari mengunduh materi peserta didik membaca, menelaah dan mempresentasikan karyanya dihadapan teman-temannya. Hasil unduh yang digunakan bahan referensi siswa dikelas merangsang siswa untuk aktif bertanya, diskusi, menanggapi, dan presentasi kelas. Rentetan keaktifan ini merupakan perilaku peserta didik yang positif untuk peningkatan prestasi belajar peserta didik dalam pembelajaran tentang menjaga keutuhan Negara Republik Indonesia pada peserta didik.

\section{METODE PENELITIAN}

Kajian tindakan kelas ini dilakukan di SDN Gegunung Kulon Kecamatan Rembang 
Kabupaten Rembang. Pelaksanaan penelitian di sekolah ini didasarkan pada pertimbangan:

(i) adanya permasalahan dalam prestasi hasil belajar secara rata-rata rendah, (ii) Nilai hasil evaluasi pada mata pelajaran Pkn dibawah ketuntasan atau belum memenuhi KKM yang ditentukan, (iii) siswa kurang antusias dalam pembelajaran PKn terutama tentang mengenal sistem pemerintahan tingkat pusat, dan (iv) sekolah telah memiliki jaringan internet.

Kajian tindakan kelas ini berlangsung selama 2 bulan yaitu bulan April 2015 sampai Mei 2015. Penelitian ini dilakukan sebanyak 2 Siklus dan 1 pembelajaran awal. Tiap Siklus berlangsung selama 140 menit (4x35 menit). Rincian kegiatan penelitian ini meliputi: persiapan penelitian, koordinasi persiapan tindakan, pelaksanaan (perencanaan, tindakan, monotoring dan evaluasi, dan refleksi), penyusunan laporan penelitian, seminar hasil penelitian, penyempurnaan laporan berdasarkan masukan seminar, serta penggandaan dan pengiriman laporan penelitian.

Subjek penelitian ini yaitu kompetensi mengenal sistem pemerintahan pusat peserta didik kelas IV SD Negeri Gegunung Kulon, Kecamatan Rembang, Kabupaten Rembang pada semester 2 tahun pelajaran 2014/2015. Jumlah siswa 14 anak terdiri atas 7 siswa lakilaki dan 7 siswa perempuan.
Teknik yang digunakan untuk mengumpulkan data berbentuk tes dan nontes. Tes digunakan untuk mengetahui prestasi peserta didik tentang pemahaman konsep mengenal sistem pemerintahan pusat. Pada setiap Siklus penulis memberikan tes akhir pembelajaran. Pada Siklus I diberikan tes tentang lembaga pemerintah pusat. Pada Siklus II, diberikan tes tentang organisasi pemerintah pusat yaitu presiden, wakil presiden dan menteri. Sedangkan teknik nontes berupa observasi dengan lembar pengamatan dan catatan harian guru/penulis. Lembar pengamatan digunakan untuk mencatat perilaku keaktifan peserta didik dalam melaksanakan tugas mengunduh materi di website, mengerjakan LKS, berdiskusi, tanyajawab, presentasi atau mengkomunikasikan hasil diskusi, dan menanggapi berbagai masalah. Catatan harian guru digunakan untuk menilai dan mendeskripsikan perubahan tingkah laku peserta didik selama kegiatan pembelajaran dilaksanakan baik pada Siklus I maupun Siklus II.

Data kuantitatif dianalisis secara deskriptif komparatif, yaitu membandingkan nilai tes kondisi awal, nilai Siklus I dan Siklus II. Sedangkan data kualitatif dianalisis secara deskriptif kualitatif berdasar hasil observasi, refleksi.

Indikator kinerja dalam penelitian ini berupa indikator keberhasilan dari penelitian tindakan kelas ini. Indikator tersebut meliputi 
(i) rata-rata nilai tes siswa kelas IV SD Negeri Gegunung Kulon tahun pelajaran 2014/2015 adalah 75,0 dan tingkat tuntas klasikal minimal 75 persen; (ii) sebagian besar siswa (75 persen) berminat melakukan tugas dalam pembelajaran; (iii) suasana pembelajaran menyenangkan, tidak membosankan; (iv) siswa memiliki pengalaman kongkrit dalam memanfaatkan website.

Prosedur penelitian Siklus I dimulai tahap perencanaan pada Siklus I berisi kegiatan Menyusun Rencana Pembelajaran yang mengakomodasi tugas proyek berbantuan website, menyiapkan lembar kerja Siswa yang mengacu pada tugas proyek yang ditugaskan pada akhir pembelajaran awal, dan menyiapkan lembar observasi aktivitas siswa dan guru, serta menyusun alat tes akhir.

Tahap Pelaksanaan Pembelajaran Siklus I diamati dengan lembar pengamatan oleh teman sejawat. Pengamatan difokuskan aktivitas peserta didik selama proses pembelajaran. Aspek-aspek tingkah laku peserta didik secara rinci dapat dilihat pada setiap lampiran RPP. Kegiatan pada tahap ini mencakup (i) siswa melakukan diskusi dari tugas proyek berupa hasil unduhan materi pembelajaran PKn yang ditugaskan minggu sebelum pembelajaran, menganalisis (eksplorasi) selanjutnya menulis hasilnya di LKS; (ii) diskusi kelompok mengerjakan LKS dan melaksanakan presentasi dari hasil kerja kelompok (elaborasi); (iii) pemantapan materi dilanjutkan evaluasi (konfirmasi); (iv) mengoreksi, menilai, dan menganalisis; serta (v) memberikan tindak lanjut (perbaikan, pengayaan, dan tuigas proyek yang kedua)

Tahap pengamatan pembelajaran Siklus I untuk mendapatkan data yang diperlukan dalam penelitian ini. Pengamatan dilakukan dengan mengumpulkan data yang diperoleh dari observasi dan tes. Pengamatan terdiri dari aktivitas siswa dengan menggunakan lember observasi terstruktur. Tes diperlukan untuk mengukur hasil belajar siswa. Nilai $\geq 68$ menyatakan siswa telah mencapai kriteria ketuntasan belajar.

Setelah melaksanakan seluruh proses pembelajaran Siklus I, guru melakukan refleksi untuk mendapatkan umpan balik tentang kinerja guru, aktivitas dan prestasi siswa sehingga dapat menentukan tindakan selanjutnya terhadap penelitian yang sedang dilakukan. Bila nilai prestasi < 68, maka perlu dilanjutkan ke pembelajaran Siklus II, dengan lebih dulu memberi tugas mengunduh materi dari website untuk kegiatan Siklus II.

Prosedur penelitian Siklus II diawali tahap perencanaan pembelajaran Siklus II, penulis melakukan persiapan (i) menyusun Rencana Pembelajaran dan skenario pembelajaran termasuk menyusun tugas proyek berbantuan website yang kedua, seminggu sebelum Siklus II dilaksanakan, (ii) menyiapkan Lembar Kerja Siswa, (iii) Menyiapkan lembar 
observasi aktivitas siswa, dan (iv) menyusun instrumen/alat tes akhir.

Tahap pelaksanaan pembelajaran Siklus II berisi kegiatan: (i) guru bersama siswa diskusi bersama untuk menganalisis hasil tugas dari website sebagai kegiatan eksplorasi, dan menuangkannya dalam LKS; (ii) mengerjakan LKS secara kelompok; (iii) presentasi siswa dari hasil kerja kelompok sebagai kegiatan elaborasi, dan siswa lain menanggapi; (iv) pemantapan materi dilanjutkan evaluasi konfirmasi; (v) mengoreksi, menilai, dan menganalisis; dan (vi) memberikan tindak lanjut (perbaikan, pengayaan, dan PR)

Tahap pengamatan pembelajaran Siklus II diperlukan untuk mendapatkan data yang diperlukan dalam penelitian ini. Pengamatan meliputi pengamatan tingkah laku siswa yang dilakukan oleh guru sebagai peneliti selama proses pembelajaran berlangsung, dengan menggunakan lembar pengamatan. Data dari hasil tes diperlukan untuk mengukur hasil belajar siswa. Nilai $\geq 68$ menyatakan siswa telah mencapai kriteria ketuntasan belajar, sedangkan nilai $<68$ menyatakan siswa belum mencapai kriteria ketuntasan belajar.
Setelah melasanakan seluruh proses pembelajaran Siklus II, guru melakukan refleksi untuk mendapatkan umpan balik tentang kinerja guru, aktivitas siswa dan prestasi siswa. Refleksi ini berguna untuk menentukan tindakan selanjutnya terhadap penelitian yang sedang dilakukan. Penelitian berhenti atau tetap berlanjut, ditentukan pada hasil refleksi ini. Bila rata-rata nilai kelas telah mencapai 75 dan tuntas klasikal telah mencapai 75 persen, penelitian berakhir. Dan bila rata-rata kelas kurang dari 75 , tuntas klasikal kurang dari 75 persen, dilanjutkan Siklus III.

\section{HASIL DAN PEMBAHASAN}

\section{Pembelajaran Awal}

Untuk pengamatan hasil belajar siswa melalui tes formatif pada materi sistem Pemerintahan Pusat, diasjikan pada tiap-tiap Siklus dan dimulai dari pembelajaran awal.

Tabel 1: Analisis Hasil Tes PKn Pembelajaran Awal

\begin{tabular}{|c|c|c|c|c|}
\hline No & Nilai & Frekuensi & Jumlah & \multicolumn{1}{|c|}{ Keterangan } \\
\hline 1 & 10 & - & & KKM $=68$ \\
\hline 2 & 20 & - & & Taraf Seraf $=62,14$ persen \\
\hline 3 & 30 & - & & \\
\hline 4 & 40 & - & & Tuntas $:=5$ siswa \\
$=36$ persen
\end{tabular}




\begin{tabular}{|c|c|c|c|c|}
\hline 6 & 60 & 6 & 360 & \\
\hline 7 & 70 & 4 & 280 & \multirow{3}{*}{$\begin{aligned} \text { Belum Tuntas: } & =9 \text { siswa } \\
& =64 \text { persen }\end{aligned}$} \\
\hline 8 & 80 & 1 & 80 & \\
\hline 9 & 90 & - & & \\
\hline 10 & 100 & - & & \\
\hline \multicolumn{2}{|c|}{ J u m l a h } & 14 & 870 & \\
\hline \multicolumn{3}{|c|}{ Rata-Rata } & 62,14 & \\
\hline
\end{tabular}

Berdasarkan Tabel 1 tentang hasil tes formatif dapat ditemukan siswa yang belum berhasil memperoleh ketuntasan belajar maupun siswa yang sudah mencapai ketuntasan belajar. Analisis daftar nilai ketuntasan menghasilkan informasi tentang siswa yang mendapat nilai tuntas sebesar 36 persen. Nilai rata-rata kelas adalah 62,14. Hasil ini jauh dari harapan.

\section{Siklus I}

\section{Proses Pembelajaran}

Pembelajaran Siklus I berlangsung selama dua pertemuan. Sesuai dengan identifikasi masalah, penulis menyusun RPP yang mengakomodasi tugas proyek berbantuan website. Tugas ini disampaikan sebelum Siklus I berlangsung. Hasil tugas dibawa pada saat pembelajaran Siklus I. Pembelajaran pertemuan pertama diawali dengan pengecekan tugas yang disusun siswa. Tugas ini berupa print out dari unduh materi dari website. Bahan unduhan ini tentang lembaga negara.

Pembelajaran dilanjutkan dengan diskusi kelompok untuk mengerjakan Lembar kerja Siswa (LKS), diskusi kelas atau presentasi, tanya jawab dengan menggunakan sumber referensi buku dan bahan unduh dari website. Pembelajaran ini diteruskan pada pertemuan kedua yang diakhiri dengan ulangan harian untuk mengetahuai prestasi siswa. Pembelajaran Siklus I ini sesuai dengan prosedur yang penulis rencanakan.

\section{Peningkatan Prestasi Belajar}

Secara umum dapat dikatakan bahwa pelaksanaan perbaikan pembelajaran pada Siklus I berjalan cukup baik. Hasil belajar siswa melalui tes formatif dapat dilihat pada Tabel 2.

Tabel 2. Analisis Hasil Tes PKn Pembelajaran Siklus I

\begin{tabular}{|c|c|c|l|l|}
\hline No & Nilai & Frekuensi & Jumlah & \multicolumn{1}{|l|}{ Keterangan } \\
\hline 1 & 10 & - & & KKM $=68$ \\
\hline 2 & 20 & - & & $\begin{array}{l}\text { Taraf Seraf }= \\
67,86 \text { persen }\end{array}$ \\
\hline 3 & 30 & - & & $\begin{array}{l}\text { Tuntas : } \\
=8 \text { siswa }\end{array}$ \\
\hline 4 & 40 & - & & 50 \\
\hline 5 & 50 & 1 & 50
\end{tabular}




\begin{tabular}{|c|c|l|l|l|}
\hline 6 & 60 & 5 & 300 & $=57$ persen \\
\hline 7 & 70 & 4 & 280 & $\begin{array}{l}\text { Belum Tuntas } \\
=6 \text { siswa } \\
=43 \text { persen }\end{array}$ \\
\hline 8 & 80 & 4 & 320 & \\
\hline 9 & 90 & & & \\
\hline 10 & 100 & & 950 & \\
\cline { 1 - 2 } J u m I a h & 14 & 67,86 & \\
\hline \multicolumn{4}{|c|}{ Rata-Rata } &
\end{tabular}

Data pada Tabel 2 menunjukkan bahwa hasil belajar siswa melalui tes formatif ada peningkatan. Terlihat dari siswa yang mendapat nilai tuntas sebesar 57 persen, sedangkan yang belum tuntas berkurang menjadi 43 persen. Sedangkan rata-rata nilai kelas mencapai 67,86. Walaupun demikian, tujuan penelitian ini belum tercapai, karena tuntas klasikal yang diharapkan adalah 75 persen, sedangkan KKM kompetensi ini adalah 68.

\section{Perubahan Perilaku Peserta Didik}

Hasil pengamatan perilaku peserta didik pada pembelajaran PKn tentang sistem Pemerintahan Pusat dalam Siklus I, dapat dilihat pada Tabel 3.

Tabel 3. Tingkat Aktivitas Siswa

\begin{tabular}{|c|l|c|c|l|}
\hline No & $\begin{array}{c}\text { Aspek yang } \\
\text { diamati/Keaktifan }\end{array}$ & $\begin{array}{c}\text { Jumlah } \\
\text { Siswa }\end{array}$ & Prosentase & Keterangan \\
\hline 1 & Aktif Unduh & 10 & 71 persen & Baik \\
\hline 2 & Disiplin melaksanakan tugas & 10 & 71 persen & Baik \\
\hline 3 & Bertanya & 11 & 78 persen & baik \\
\hline 4 & Semangat & 9 & 64 persen & cukup \\
\hline 5 & Menanggapi & 7 & 50 persen & cukup \\
\hline 6 & Kreativitas Kerja & 8 & 57 persen & cukup \\
\hline
\end{tabular}

Berdasarkan Tabel 3 dapat dijelaskan bahwa terjadi perubahan perilaku peserta didik dari kurang aktif menjadi aktif. Walaupun belum semua siswa dalam kategori baik aktif tetapi telah menunjukkan perubahan positif untuk aktif mengunduh materi, disiplin dan senang melaksanakan tugas. Beberapa aspek keaktifan siswa masih dalam kategori cukup aktif yaitu kemampuan bertanya, menanggapi, dan kreativitas.

\section{Refleksi I}

Hasil refleksi Siklus I dapat disampaikan adanya kelebihan dan kekurangan pembelajaran Siklus I. Pada pembelajaran Siklus I telah terjadi peningkatan prestasi yang semula pada konsisi awal rata-tara kelas 62.14 menjadi 67.86. Tingkat klasikal semula 36 persen menjadi 57 persen pada Siklus I ini. Demikian juga perilaku peserta didik mulai 
aktif dan senang melaksanakan tugas dengan mengunduh materi berbantuan website. Sedangkan kekurangan dari pembelajaran Siklus I ini adalah siswa masih tampak raguragu dalam browsing internet.

\section{Proses Pembelajaran}

Pembelajaran Siklus II berlangsung selama dua pertemuan. Sebagaimana pembelajaran Siklus I, guru menyusun RPP yang mengakomodasi tugas proyek berbantuan website. Tugas ini disampaikan sebelum Siklus II berlangsung. Hasil tugas dibawa pada saat pembelajaran Siklus I. Pembelajaran pertemuan pertama diawali dengan pengecekan tugas yang disusun siswa. Tugas ini berupa print out dari unduh materi dari website. Bahan unduhan ini tentang tugas pokok dan fungsi dari presiden, wakil presiden, dan menteri.
Melihat hasil yang dicapai siswa belum memenuhi target indikator kinerja, yaitu tuntas klasikal 75 persen, yang dicapai baru 57 persen maka pembelajaran dilanjutkan ke Siklus II.

\section{Hasil Penelitian Siklus II}

Pembelajaran dilanjutkan dengan diskusi kelompok untuk mengerjakan lembar kerja siswa, diskusi kelas atau presentasi, tanya jawab dengan menggunakan sumber referensi buku dan bahan unduh dari website. Pembelajaran ini diteruskan pada pertemuan kedua yang diakhiri dengan ulangan harian untuk mengetahuai prestasi siswa. Pembelajaran Siklus II ini sesuai dengan prosedur yang peneliti rencanakan.

\section{Peningkatan Prestasi Belajar}

Hasil belajar peserta didik melalui tes formatif dapat dilihat pada Tabel 4 . 
Tabel 4. Analisis Hasil Tes PKn Pembelajaran Siklus II

\begin{tabular}{|c|c|c|c|c|}
\hline No & Nilai & Frekuensi & Jumlah & Keterangan \\
\hline 1 & 10 & - & & $\mathrm{KKM}=68$ \\
\hline 2 & 20 & - & & \multirow{2}{*}{$\begin{array}{l}\text { Taraf Seraf }= \\
78,57 \text { persen }\end{array}$} \\
\hline 3 & 30 & - & & \\
\hline 4 & 40 & - & & \multirow{3}{*}{$\begin{array}{l}\text { Tuntas : } \\
=12 \text { siswa } \\
=86 \text { persen }\end{array}$} \\
\hline 5 & 50 & - & & \\
\hline 6 & 60 & 2 & 120 & \\
\hline 7 & 70 & 4 & 280 & \multirow{3}{*}{$\begin{array}{l}\text { Belum Tuntas } \\
=2 \text { siswa } \\
=14 \text { persen }\end{array}$} \\
\hline 8 & 80 & 4 & 320 & \\
\hline 9 & 90 & 2 & 180 & \\
\hline 10 & 100 & 2 & 200 & \\
\hline \multicolumn{2}{|c|}{ J u m l a h } & 14 & 1100 & \\
\hline \multicolumn{3}{|c|}{ Rata-Rata } & $\mathbf{7 8 , 5 7}$ & \\
\hline
\end{tabular}

Hasil analisis data pada Tabel 4 sistem Pemerintahan Pusat dapat dijelaskan bahwa pada Siklus II nilai ketuntasan dan rata-rata siswa mengalami kenaikan lebih besar, dari 57 persen pada Siklus I menjadi 86 persen pada Siklus II. Rata-rata kelas dari 67,86 pada Siklus I, menjadi 78,57 pada Siklus II. Sedangkan nilai yang belum tuntas menjadi semakin turun dari 43 persen (6 siswa) pada
Siklus I menjadi 14 persen (2 siswa) pada Siklus II.

\section{Perubahan Perilaku Peserta Didik}

Hasil pengamatan perilaku peserta didik pada pembelajaran PKn tentang sistem Pemerintahan Pusat dalam Siklus II, dapat dilihat pada Tabel 5 .

Tabel 5. Tingkat Aktivitas Siswa

\begin{tabular}{|c|l|c|c|l|}
\hline No & \multicolumn{1}{|c|}{ Aspek yang diamati / Keaktifan } & Jumlah Siswa & Prosentase & Keterangan \\
\hline 1 & Aktif Unduh & 13 & 93 persen & Baik \\
\hline 2 & Disiplin melaksanakan tugas & 13 & 93 persen & Baik \\
\hline 3 & Bertanya & 10 & 71 persen & Baik \\
\hline 4 & Semangat & 14 & 100 persen & Baik \\
\hline 5 & Menanggapi & 11 & 78 persen & Baik \\
\hline 6 & Kreativitas Kerja & 12 & 86 persen & Baik \\
\hline
\end{tabular}

Berdasarkan Tabel 5 dapat dijelaskan bahwa tingkat keaktifan siswa makin baik dibanding Siklus I. Aspek aktivitas peserta didik yang penulis rencanakan seperti aktif unduh, disiplin melaksanakan tugas, bertanya, semangat, menanggapi, dan kreativitas kerja makin baik, sampai mencapai 100 persen peserta didik. 


\section{Refleksi II}

Hasil refleksi guru dan teman sejawat telah menemukan kepuasan hasil belajar siswa yang mengalami kemajuan terbukti dengan nilai hasil belajar siswa dari Siklus I ke Siklus II, menjadi lebih meningkat. Nilai ketuntasan belajar siswa meningkat 70 persen, menjadi 90 persen hal ini menunjukkan bahwa siswa mampu menguasai materi tentang sistem Pemerintahan Pusat beserta nilai kebersamaan dan nilai juangnya dengan baik, yang berarti juga siswa telah mempunyai pemahaman yang baik melalui pemanfaatan teknologi informasi.

Skenario pembelajaran berjalan lancar. Tugas proyek dikerjakan dengan baik dan penuh semangat dengan suasana yang menyenangkan. Sehingga tersusun modul atau diktat materi sistem Pemerintahan Pusat, nilai Kebersamaan dan nilai Juangnya. Berdasarkan hasil refleksi juga ditemukan bahwa materi telah dipahami oleh siswa dengan nilai hasil belajar siswa rata-rata 71 dari Siklus I menjadi 80 pada Siklus II. Dan ketuntasan telah mencapai 90 persen. Oleh karena itu penulis memutuskan mengakhiri perbaikan pembelajaran pada Siklus II dan menganggap perbaikan pembelajara sudah selesai.

\section{Proses Pembelajaran}

Proses pembelajaran PKn tentang sistem pemerintahan tingkat pusat pada siswa kelas IV SD Negeri Gegunung Kulon Rembang semester 2 tahun pelajaran 2014/2015 dapat berjalan sesuai dengan rencana. Pembelajaran yang terencana dengan melibatkan peserta didik secara aktif akan menghasilkan prestasi siswa yang optimal sesuai tahap-tahapnya. Demikian juga dalam penggunaan metode dan medianya. Dalam penelitian ini penulis memanfaatkan media website atau internet sebagai bantuan pengerjaan tugas.

Dalam proses pembelajaran yang menggunakan banyak referensi dari website peserta didik merasa senang dan bebas berekspresi dengan berbagai sumber. Melalui website ini siswa mencari informasi sebanyakbanyaknya tentang sistem pemerintahan pusat sehingga banyak informasi yang diperoleh dan dipahami siswa. Hal ini sesuai pendapat Haryono dan Jaino (2008) bahwa pembelajaran yang membebaskan, yang tidak membelenggu dan memenjarakan kebebasan peserta didik untuk berekspresi, bereksperimen, dan berprakarsa untuk mengembangkan kreativitas dan bersikap kritis, serta penuh tanggungjawab.

Berdasarkan deskripsi tersebut, maka hipotesis tindakan yang diajukan dapat diterima, yaitu pemberian tugas proyek berbantuan website dapat meningkatkan keaktifan peserta didikkelas IV SDN Gegunung Kulon Rembang Semester 2 tahun pelajaran 2014/2015. Hal ini ditandai adanya peningkatan aktifitas siswa seperti unduh materi, semangat, kreatifitas, dan disiplin dalam melaksanakan tugas pembelajaran tentang sistem pemerintahan pusat. 


\section{Peningkatan Prestasi belajar}

Proses pembelajaran Siklus I telah dibantu dengan hasil unduhan siswa dari internet tentang sistem pemerintahan tingkat pusat. Hasil unduhan itu digunakan untuk mengerjakan lembar kerja dan sumber informasi bagi pengembangan wawasan untuk evaluasi formatif.

Dari data hasil belajar siswa malalui tes formatif ternyata siswa belum dapat mencapai hasil belajar yang diharapkan, hal ini menjadi pertimbangan penulis ternyata tingkah laku siswa dan guru mempunyai hubungan yang saling mempengaruhi terhadap hasil belajar. Tes hasil belajar Siklus 1 rata-rata kelas telah mencapi 67,86 belum mencapai KKM 68, ketuntasan mencapai 57 persen. Hasil ini belum sesuai harapan peneliti.

Walaupun demikian nilai hasil belajar siswa Siklus I, menjadi lebih meningkat dibanding pada pembelajaran awal. Nilai ketuntasan belajar siswa dari 36 persen, menjadi 57 persen hal ini menunjukkan bahwa usaha yang dilakukan guru dalam perbaikan pembelajaran menunjukkan perubahan positif. Sedangkan nilai rata-rata kelas dari 62,14 pada pembelajaran awal menjadi 67,86 pada Siklus I. Perbaikan pembelajaran pada penelitian ini akan dilanjutkan pada Siklus II, karena tujuan penelitian belum berhasil mencapai tuntas 75 persen dan rata-rata kelas minimal 75.
Kegiatan evaluasi pada Siklus II ini dapat dilaksanakan dengan penuh semangat oleh siswa. Mereka telah menguasai materi pelajaran dengan baik. Pada Siklus II ini hasil belajar siswa telah menunjukkan kemajuan yang memuaskan. Nilai hasil belajar meningkat lebih tinggi dibandingkan dengan nilai hasil belajar pada Siklus sebelumnya, demikian juga jumlah siswa semakin banyak yang mencapai KKM. Pada Siklus I nilai ratarata kelas mencapai 67,86, meningkat pada Siklus II menjadi 78,57 dengan tingkat klasikal mencapai 86 persen. Hal ini menunjukkan bahwa perbaikan pembelajaran yang dilakukan telah berhasil mencapai tujuan yang diharapakan karena dari tes yang diberikan telah dapat mengukur tingkat pemahaman siswa yaitu mencapai standard yang ditetapkan.

Nilai hasil belajar siswa dari Siklus I ke Siklus II, menjadi lebih meningkat. Nilai ketuntasan belajar siswa meningkat 57 persen, menjadi 86 persen hal ini menunjukkan bahwa siswa mampu menguasai tentang sistem pemerintahan pusat dengan baik, yang berarti juga siswa telah mempunyai pemahaman yang baik melalui pemanfaatan teknologi informasi. Skenario pembelajaran berjalan lancar. Tugas proyek dikerjakan dengan baik dan penuh semangat dengan suasana yang menyenangkan. Sehingga tersusun modul atau diktat materi sistem pemerintahan pusat. Berdasarkan hasil refleksi juga ditemukan bahwa materi telah dipahami oleh siswa 
dengan nilai hasil belajar siswa rata-rata 67,86 dari Siklus I menjadi 78,57 pada Siklus II. Dan ketuntasan telah mencapai 86 persen. Oleh karena itu penulis memutuskan mengakhiri perbaikan pembelajaran pada Siklus II dan menganggap perbaikan pembelajaran sudah selesai dan tujuan penelitian tercapai. Keberhasilan siswa menguasai materi sistem pemerintahan pusat sesuai dengan pendapat Mampuono (2009) bahwa website atau internet merupakan media yang kaya informasi yang dapat dijadikan media pembelajaran yang baik, yang dapat membantu guru dan siswa dalam pembelajaran.

Berdasarkan uraian di atas, hipotesis tindakan yang diajukan dapat diterima yaitu penggunaan metode tugas proyek berbantuan website dapat meningkatkan prestasi belajar peserta didik dalam pembelajaran PKn tentang sistem pemerintahan pusat pada peserta didik kelas IV SD Negeri Gegunung Kulon Rembang semester 2 tahun pelajaran 2014/2015.

\section{Perubahan Perilaku Peserta Didik}

Siswa berhasil mengunduh materi seputar sistem pemerintah pusat bagian presiden, wakil presiden, dan menteri dengan menjelajah website atau internet. Hasil unduhan para siswa dikumpulkan menjadi modul atau diktat sistem pemerintah pusat karya Kelas IV SDN Gegunung Kulon Semester 2 Tahun Pelajaran 2014/2015.

Peserta didik dengan penuh semangat dan senang dalam melaksanakan tugas-tugas yang dibebankan padanya. Sehingga yang semula kurang aktif menjadi aktif dan yang kurang semangat menjadi semangat. Pemberian tugas dengan bantuan website mengajak siswa untuk semangat dan memperoleh informasi yang sebanyak-banyaknya. Hal ini merupakan bukti bahwa perubahan perilaku peserta didik terjadi signifikan. Hal ini sejalan dengan pendapat yang dikemukakan Ruminiati (2006: II.7) bahwa pemberian tugas dapat memupuk semangat belajar siswa. Dengan demikian hipotesis tindakan yang diajukan dapat diterima yaitu pemberian tugas proyek berbantuan website diduga dapat mengubah perilaku belajar tentang sistem pemerintahan pusat pada peserta didik kelas IV SD Negeri Gegunung Kulon Rembang semester 2 tahun pelajaran 2014/2015.

\section{KESIMPULAN DAN SARAN}

\section{Simpulan}

Simpulan dari penelitian ini adalah: (i) pemberian tugas proyek berbantuan website dapat meningkatkan keaktifan peserta didik dalam pembelajaran PKn tentang sistem pemerintahan pusat; (ii) penggunaan metode tugas proyek berbantuan website dapat meningkatkan prestasi belajar peserta didik dalam pembelajaran tentang sistem pemerintgahan pusat yang ditandai dengan peningkatan rata-rata prestasi siswa dari 62,14 pada awal, menjadi 67,86 pada Siklus I, dan 
78,57 pada Siklus II. Demikian juga tingkat ketuntasan belajar secara klasikal dari 36 persen menjadi 57 persen, dan akhirnya 86persen.; dan (iii) pemberian tugas proyek berbantuan website dapat mengubah perilaku belajar tentang sistem pemerintahan pusat pada peserta didik kelas IV SD Negeri Gegunung Kulon Rembang semester 2 tahun pelajaran 2014/2015.

\section{Saran}

Prestasi siswa kelas IV SD Negeri Gegunung Kulon pada pembelajaran PKn tentang sistem pemerintahan pusat perlu dipertahankan, oleh karena itu guru hendaknya melaksanakan tindakan-tindakan perbaikan tersebut di atas bahkan bila memungkinkan dicari alternatif lain yang yang dapat meningkatkan kemampuan siswa. Kepada teman guru agar memanfaatkan teknologi informasi untuk memperluas wawasan, dan informasi dalam pembelajaran agar senantiasa tercipta pembelajaran yang menyenangkan. Untuk sekolah agar dapat mendokumentasikan segala hasil karya guru termasuk hasil penelitian tindakan kelas ini, agar dapat dijadikan referensi oleh sesama guru. Untuk Pemerintah agar melengkapi sarana teknologi agar sekolah dapat memanfatkan dunia internet dengan baik. 


\section{DAFTAR PUSTAKA}

Depdiknas, 2004. Standar Isi, Standar Kompetensi dan Kompetensi Dasar, SD dan MI. Jakarta : Depdiknas.

Harlina, Siti, Hasdin, dan Arif Firmansyah, 2014. Penerapan Metode Pemberian Tugas untuk Meningkatkan Rasa Tanggungjawab dalam Pembelajaran PKn di Kelas III SDN Baho Makmur Kecamatan Bahodopi Kabupaten Morowali. Jurnal Kreatif Tadulako Online Vol. 3 No. 1 ISSN 2354-614X, diakses dari jurnal.untad.ac.id/jurnal, tanggal 15 April 2015

Haryano dan Jaino, 2008, Prinsip-Prinsip Pembelajaran yang Mendidik di SD, Bahan Ajar Program sertifikasi Guru dalam Jabatan Melalui Jalur Pendidikan, Semarang : Unnes.

Mampuono, 2009, Pemanfaatan Internet dan Multimedia Guna Meningkatkan Kualitas Pembelajaran. Makalah disampaikan dalam Seminar Nasional Klub Guru Indonesia di Rembang, 7 Juni 2009.

Pawestri, Inggit Asih, (2013). Peningkatan kualitas Pembelajarn PKn Melalui Model Direct Instruction Berbasis Multimedia Pada Siswa Kelas VB SDN Sampangan 02 Kota Semarang, Sripsi, Jurusan PGSD, Fakultas Ilmu Pendidikan, Unnes Semarang, diakses dari http://lib.unnes.ac.id/, tanggal 15 Maret 2015.

Pertiwi Cyntia, Sukadi, dan I Nyoman Pursika, 2008. Penerapan Strategi Pembelajaran ELearning Untuk Meningkatkan Hasil Belajar Siswa Dalam mata Pelajaran PKn Pada Siswa Kelas X Tataniaga B Di SMK Negeri 1 Singaraja, diakses dari ejournal.undiksha.ac.id, tanggal 15 Maret 2015

Prayoga Bestari dan Ati Sumiati, 2008, Pendidikan Kewarganegaraan, Untuk SD dan MI

Kelas IV, Jakarta : Pusat Perbukuan, Departemen Pendidikan Nasional.

Rahmawati, Fitri, 2008. Model Pembelajaran e-LearningUntuk Meningkatkan Kualitas Pendidikan. Yogyakarta : UNY

Ruminiati, 2008. Bahan Ajar Cetak, Pembelajaran PKn SD. Jakarta : Konsorsium Program PJJ S1 PGSD, Direktorat Jenderal Pendidikan Tinggi, Departemen Pendidikan Nasional.

Solikhin, Akhmad, 2008. Penggunaan ICT (Information, Communication and Technology) Dalam Pembelajaran: Perspektif Mata Pelajaran Matematika, IPA, IPS dan PKn di Sekolah Dasar. diakses dari http://akhmadsolikhin.worpress.com, tanggal 15 Maret 2015

Tijan, 2008, Pendidikan Kewarganegaraan SD, Bahan Ajar Program Sertifikasi Guru dalam Jabatan melalui Jalur Pendidikan, Semarang : Unnes. 


\title{
KAJIAN PENYELENGGARAAN PENDIDIKAN KARAKTER DI SMA DAN SMK

\author{
STUDY ON THE IMPLEMENTATION OF CHARACTER EDUCATION IN SENIOR HIGH \\ SCHOOL (SMA) AND VOCATIONAL SCHOOL (SMK)
}

\author{
Sudiyono \\ Pusat Penelitian Kebijakan Pendidikan dan Kebudayaan, Balitbang Kemdikbud \\ J1. Jenderal Sudirman, Senayan Jakarta \\ e-mail:sudiyono_d@ymail.com \\ Diterima: 29/02/2016; dikembalikan untuk direvisi: 29/03/2016, disetujui: 16/04/2016
}

\begin{abstract}
ABSTRAK
Penelitian ini bertujuan untuk mendapatkan informasi tentang pelaksanaan pendidikan karakter, guna mendapatkan opsi kebijakan tentang strategi pendidikan karakter di sekolah. Metode penelitian menggunakan survei, menggunakan pendekatan deskriptif kualitatif dan analisis data menggunakan statistik deskriptif. Penelitian dilaksanakan di 10 kab/kota dengan sampel 40 SMA dan 40 SMK. Responden adalah kepala dinas pendidikan 10 orang, kepala sekolah 80 orang, guru 320 orang, dan siswa 800 orang. Hasil penelitian menunjukkan bahwa dari sisi kebijakan pemerintah daerah sebagian besar belum menerbitkan peraturan daerah yang terkait dengan pendidikan karakter. Sementara pada tingkat sekolah, kebijakan pelaksanaan pendidikan karakter umumnya dilaksanakan mengacu pada visi dan misi sekolah, sebagian besar sekolah mengintegrasikan dalam pembelajaran, pembiasaan, dan pembudayaan. Pelaksanaan pembiasaan dan pembudayaan yang dilakukan oleh guru masih belum konsisten, dan belum dievaluasi secara periodik. Direkomendasikan perlu adanya penguatan dan pembudayaan secara konsisten pelaksanaan pendidikan karakter dengan mengacu pada praktik sekolah terbaik dan meminimalkan hambatan pelaksanaannya.
\end{abstract}

Kata Kunci: Pendidikan karakter, kebijakan pendidikan karakter, Pendidikan Menengah (SMA dan SMK).

\section{ABSTRACT}

This study aimed to obtain information on the implementation of character education in academic and vocational high school in order to develop strategic policy options on character education in schools. The method used was survey, descriptive qualitative approach and data analysis using descriptive statistics. The research was conducted in 10 districts/cities with a sample of 80 schools (40 academic schools and 40 vocational schools). Respondents involved were 10 district head of education offices, 80 principals, 320 teachers, and 800 students. The results showed that in terms of policy, most regional government had yet to issue local regulations related to character education. While at the school level, policy implementation was generally implemented in reference to the vision and mission of the school. The vast majority of schools integrated learning, habituation, and familiarization. Implementation of habituation and familiarization done by teachers were still inconsistent, and had not been evaluated periodically. One of policy recommendation is the need to strengthen and develop a consistent implementation of character education referencing to the best practices and to minimize obstacles in implementation.

Keywords: Character education, character education policy, Secondary Education (high school and vocational). 